International Journal of Current Advanced Research

ISSN: O: 2319-6475, ISSN: P: 2319 - 6505, Impact Factor: SJIF: 5.995

Available Online at www.journalijcar.org

Volume 6; Issue 4; April 2017; Page No. 3361-3363

DOI: http://dx.doi.org/10.24327/ijcar.2017.3363.0273

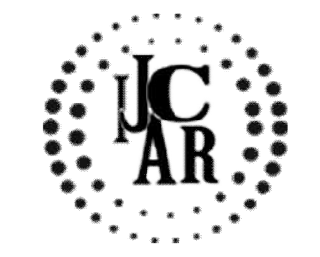

Research Article

\title{
ASSESSMENT OF KNOWLEDGE REGARDING THE SUCCESS OF VITAL PULP THERAPY AMONG DENTAL COLLEGE STUDENTS OF CHENNAI
}

\author{
Deepti Anna John* and Manish Ranjan
}

Department of Conservative Dentistry and Endodontics, Saveetha Dental College, Saveetha University, Chennai, TamilNadu, India

\begin{tabular}{l}
\hline A R T I C L E I N F O \\
Article History: \\
Received $6^{\text {th }}$ January, 2017 \\
Received in revised form $10^{\text {th }}$ February, 2017 \\
Accepted $12^{\text {th }}$ March, 2017 \\
Published online $28^{\text {th }}$ April, 2017
\end{tabular}

Key words:

Deep caries management, awareness, vital pulp therapy

\begin{abstract}
A B S T R A C T
Aim: To gain an overview of the knowledge regarding the success of vital pulp therapy among dental college students in Chennai.

Objective: The purpose of the study is to understand whether the students are aware of vital pulp therapy and its success.

Background: Dental pulp is an unmineralized oral tissue containing soft connective, vascular, lymphatic and nervous elements which occupies the central pulp chamber. It is the most vital part of the tooth. Vital pulp therapy is done to maintain the vitality and preserve the pulp tissue that is compromised and is indicated depending on the amount of exposure of the pulp and presence of infection. The different types of vital pulp therapy are indirect pulp capping, direct pulp capping and pulpotomy. Vital pulp therapy is also indicated for open apex to ensure proper root growth.

Materials and Method: Questionnaire was handed out to 200 dental college students in Chennai

Reason: To create awareness about vital pulp therapy among people to conserve the vitality of the tooth rather than invasive treatment such a root canal treatment.
\end{abstract}

Copyright $₫ 2017$ Deepti Anna John and Manish Ranjan. This is an open access article distributed under the Creative Commons Attribution License, which permits unrestricted use, distribution, and reproduction in any medium, provided the original work is properly cited.

\section{INTRODUCTION}

The tooth is composed of three basic parts enamel, dentin and pulp. Out of which the dental pulp is one of the most unique and important. Situated with the rigid pulp chamber, the pulp is composed of umineralized connective tissue along with blood vessels, lymph vessels and nerves, making it the vital organ of the tooth. The pulp is always under constant threat from varied factors such as stimuli from the mouth - caries, cracks, fractures etc. that provide pathways for the microorganisms and their toxic products to enter [1]. Hence it is important to safeguard and preserve the vitality of the tooth. This can be achieved by restorative treatments, but in the case of deep caries and caries that has infected the pulp, alternative treatment options such as vital pulp therapy which includes direct pulp capping, indirect pulp capping and pulpotomy can be done to save the vitality of the tooth rather than proceeding with invasive treatment options such as root canal treatment. The main objective of pulp treatment is to maintain the integrity and health of the oral tissues, even though the tooth can remain non-functional, it is necessary to try in restoring the vitality of the pulp. [2]. Therefore, the aim of vital pulp therapy is to treat the reversible pulpal injury.

*Corresponding author: Deepti Anna John

Department of Conservative Dentistry and Endodontics, Saveetha Dental College, Saveetha University, Chennai, TamilNadu, India
The molecular and cellular changes that take place during tooth development and during tooth repair both show similarity indicating the method with which the various pulp treatment will work. In Dentinogenesis, the odontoblasts that are derived from the dental papilla secrete primary dentine during the post mitotic state, the cells of the pulp do not play any role in primary dentine formation. After a bulk of dentine has been formed, secondary dentine at a slower rate is deposited reducing the pulp chamber size.The post mitotic odontoblasts remain in a dormant state unless subjected to injury. $[3,4]$ In the case of injury, the dentin and pulp complex secrete tertiary dentin increasing the distance between the injury and the healthy cells [5]. The tertiary dentin formed can be of two types reactionary and reparative depending on the severity of the injury to the pulp.

This forms the basis of vital pulp therapy. Indirect pulp capping is done in the case of deep carious lesions without any pulpal exposure. In this procedure, the deep carious dentin remains with a layer of calcium hydroxide to prevent additional trauma to the pulp and to initiate the tertiary dentin formation. Over the protective liner, temporary filling such as zinc oxide eugenol or glass ionomer cement [4]. The rationale of indirect pulp therapy is that the remaining bacteria present in the cavity will get sealed and become inactive. After indirect pulp therapy, a permanent restoration is placed. The only contraindication is that this treatment may lead to pulp 
exposure and trauma [7]. Direct pulp capping is done in the case of pulpal exposure during trauma or treatment. The exposure site is asymptomatic and is pin point in size. Calcium hydroxide liner is placed to initiate dentin growth and heal the pulp, hence maintaining the vitality of the tooth. [8] This treatment is ideal for young permanent teeth, failure could lead to internal resorption or dentoalveolar abscess.

Pulpotomy is done when the radicular pulp is capable of healing once the infected Coronal pulp is surgically removed [9]. It is contraindicated if the infection spreads towards the radicular pulp and in cases of fistula, pathological movement etc. The medicament used should be bactericidal and harmless to the surrounding structures. Studies have revealed $84 \%$ success rate.

\section{Aim}

The aim of the study by the means of a questionnaire was to assess the knowledge about vital pulp therapy and its success and if it was the preferred method of treatment of deep caries and pulp exposure among dental students.

\section{MATERIALS AND METHODS}

The study was designed to evaluate the level of knowledge about vital pulp therapy among dental students in Chennai,Tamil Nadu.The study was focused on the different types of pulp therapy,its indications and objectives,materials used in the treatment process, age groups in which pulp therapy is preferred treatment option and treatment outcome. 200 dental students participated in this questionnaire survey. The group consisted of both undergraduate and post graduate students. The questionnaire consisted of 11 questions in English.

\section{RESULTS}

The participation rate is $100 \%$ with an overall sample size $(n=200)$. The study group consisted of UG $(n=150)$ and PG $(\mathrm{n}=50)$.

From the given survey, the following results were obtained:

\section{Table 1}

\begin{tabular}{cc}
\hline & Overall Sample (n=200) \\
\hline Level of Awareness of Vital pulp therapy & $96 \%(192)$ \\
Under Graduate dental students $(n=150)$ & $94.6 \%(142)$ \\
Post graduated dental students $(n=50)$ & $100 \%(50)$ \\
\hline
\end{tabular}

\section{Level of Knowledge about Vital Pulp Therapy}

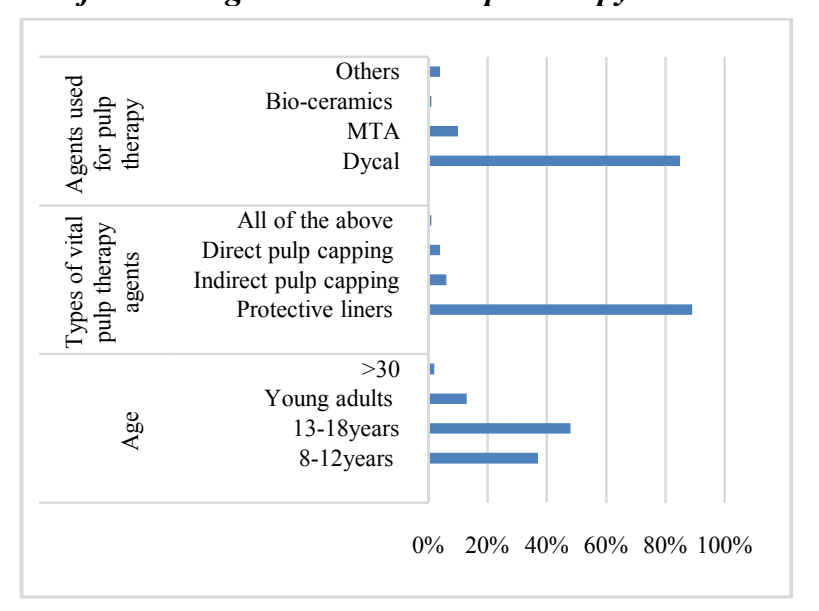

\section{DISCUSSION}

The study reveals that vital pulp therapy is known to most dental students but the level of knowledge about the procedure is varied.The results show that the undergraduate dental students need to gain more knowledge about this type of treatment. Most of the students knew the basic facts about vital pulp therapy, but didn't know the exact information about it.Vital pulp therapy is indicated for reversible pulpitis and Coronal exposure of pulp, about $44 \%$ of the students selected reversible pulpitis, $26 \%$ irreversible pulpitis and $24 \%$ exposed pulp.The main objectives of vital pulp therapy is to make sure there is no post treatment symptoms, maintaining the vitality of the tooth, removal of caries and infected pulp.About $83 \%$ students stated that the main objective is- no post treatment symptoms and remaining $17 \%$ stated that maintaining vitality was important. For deep carious management, indirect pulp capping is the most common method of treatment and it's indicated for reversible pulpitis which $80 \%$ of the students selected. The success of this treatment is determined by growth of tertiary dentin and absence of secondary infection. But only $28 \%$ of the students stated that tertiary dentin growth was important and gave more importance to prevention of secondary caries. About $54 \%$ students detected the vitality of the tooth with the thermal test method which is a sensibility test but the exact method to detect vitality is the pulp oximetry test. Majority of the dental students who preform vital pulp therapy use Zinc oxide eugenol or Glass ionomer cement as a temporary filling until the patient is recalled and given a permanent filling of amalgam, onlay, inlay and stainless steel crowns depending on whether the treatment was a success.

From studies previously conducted, it proven that the success rate of vital pulp therapy is $95 \%$. But the success depends on various factors such as tooth location in the dental arch - A study done by Sveen in 1969 stated that first primary molars treated by indirect pulp therapy are more likely to fail than second primary molars [10] and hence pulpotomy is done with the first molars [11]. The second factor that affects success rate is the type of restorative material used after pulp therapy- amalgam has more failure rates than compared with Stainless steel crowns. The third factor is the placement of $\mathrm{Ca}(\mathrm{OH})$ with Zinc oxide eugenol which was traditionally used in the 1970's is more successful than just the placement of $\mathrm{Ca}(\mathrm{OH})$.

From another study, it was indicated that age, gender, level of experience and caries level assessment have no significance in the success of pulp therapy. The careful diagnosis along with proper removal of caries from the walls and preventing the deep carious dentin from Microscopic exposure along with the use of dentin bonding agents will lead to success in pulp therapy.

\section{CONCLUSION}

From the study, it is concluded that most dental students are aware of vital pulp therapy, but do not prefer to do the procedure in cases other than reversible pulpitis and lack proper knowledge about vital pulp therapy. Vital pulp therapy is done to ensure and conserve the vitality of the tooth rather than doing invasive procedures such as Root canal treatment, as preservation of what remains is of utmost importance. 


\section{References}

1. Yu.C, AbbottPV. An Overview of the dental pulp: its functions and responses to injury. Aus. Dent J. 2007 Mar; 52 (1 suppl): s4-s16.

2. American Academy of PaediatricDentistry, Reference Manual 2001-2002: clinical guidelines for pulp therapy for primary and young permanent teeth. pp58-61

3. Linde. A, Goldberg M. Dentinogenesis.Crit Rev Oral Biol Med 1993; 4(5):679-728

4. Baume LJ. The biology of pulp and dentin. In: MyersHM, editor. Monographs in oral science. Basel: $S$ Karger $A G ; 1980$

5. Fuks AB. Current concepts in vital primary pulp therapy. Eu J Pediatr Dent.2002;115-120
6. Sveen OB. Pulp capping of primary teeth with zinc oxide eugenol. Odontologisk Tidskrift.1969;77:427-436

7. Dumsha T, Hovland E. Considerations and treatment of direct and indirect pulp-capping. Dent Clin North Am 1985 Apr; 29(2):251-9.

8. Levine N, Pulver F, Torneck CD. Pulpal therapy in primary and young permanent teeth. In Wei SHY (ed): Pediatric Dentistry- Total Patient Care. Philadelphia: Lea \& Febige; 188

9. Fuks $\mathrm{AB}$, Eidelman E. Pulp therapy in the primary dentition. Curr Opin Dent 1991 Oct;1(5):556-63.

10. Farooq NS, Coll J, Kawabara A, Shelton P, Success rates of formocresol pulpotomy and indirect pulp therapy in treatment of deep dentinal caries in primary teeth. Pediatr Dent.2000;22: 278-286

11. Mohammed AA, LloydH. S, RobertJF, Welch K.B. Indirect pulp treatment of primary posterior teeth- A retrospective study. Pediatr Dent 25:1,2003

\section{How to cite this article:}

Deepti Anna John and Manish Ranjan (2017) ' Assessment Of Knowledge Regarding The Success Of Vital Pulp Therapy Among Dental College Students Of Chennai', International Journal of Current Advanced Research, 06(04), pp. 3361-3363. DOI: http://dx.doi.org/10.24327/ijcar.2017.3363.0273 